Review Article

\title{
Diagnosis and Prognosis of Prostate Cancer from Circulating Matrix Metalloproteinases and Inhibitors
}

\author{
William Khalil El-Chaer, ${ }^{1}$ Clayton Franco Moraes, ${ }^{1,2}$ and Otávio Toledo Nóbrega (iD) ${ }^{1}$ \\ ${ }^{1}$ University of Brasília (UnB), 70910-900 Brasília, DF, Brazil \\ ${ }^{2}$ Catholic University of Brasília (UCB-DF), 71966-700 Brasilia, DF, Brazil
}

Correspondence should be addressed to Otávio Toledo Nóbrega; otnobrega@gmail.com

Received 18 April 2018; Accepted 11 June 2018; Published 10 July 2018

Academic Editor: Carmela R. Balistreri

Copyright (c) 2018 William Khalil El-Chaer et al. This is an open access article distributed under the Creative Commons Attribution License, which permits unrestricted use, distribution, and reproduction in any medium, provided the original work is properly cited.

\begin{abstract}
Although prostate cancer $(\mathrm{PCa})$ is the sixth most common type of neoplasm in the world and the second in prevalence among men ( $10 \%$ of all cases), there is shortage of studies focused on primary prevention of the disorder as well as little understanding on its pathophysiology. Currently, the PCa screening tools are the prostate specific antigen (PSA) dosage conjugated to rectal examination and confirmed by prostate biopsy. Despite the name, the PSA presents reduced specificity, being necessary the identification of new biomarkers that allow an earlier and more precise diagnosis and even better prognosis. Several studies have associated matrix metalloproteinases (MMPs) and their tissue inhibitors (TIMPs) to PCa tumorigenesis and metastasis. Most of the studies so far have been carried out by investigating in situ expression of the metalloproteinases, either by transcriptional measures or by immunohistochemistry with biopsy or postoperative tissue. Investigations in human plasma and serum are scarce, and a bibliographical search resulted in 17 studies which are presented and interpreted herein. This narrative review discusses their settings and findings along with aspects related to circulating metalloproteinases as potential biomarkers for diagnosis or prognosis of the prostatic malignancy, expressing the authors' reticent view on their applicability due to the poor quality of evidence available.
\end{abstract}

\section{Introduction}

Statistics worldwide indicate that prostate cancer (PCa) has high prevalence and lethality, with three-quarters of cases among 65-year-oldsters [1]. Serum prostate specific antigen (PSA) levels are measured for early detection, staging, and monitoring despite not being a specific marker for $\mathrm{PCa}$, rising in cases of prostatitis or benign prostatic hyperplasia $(\mathrm{BPH})[2,3]$.

Biochemical evidence indicates that serum proteinases, namely, matrix metalloproteinases (MMPs), play key roles in the pathophysiology of this malignancy. MMPs are zincor calcium-dependent endopeptidases that degrade various components of extracellular matrix, mainly collagen, elastin, laminin, fibronectin, and proteoglycans, being involved in tumorigenesis and metastasis to favor migration of tumor cells besides being proangiogenic [3].
Twenty-four MMPs have been identified, including collagenases (MMP-1, 8, 13, and 18), gelatinases (MMP-2 and 9), stromelysins (MMP-3 and 10), matrilisins (MMP-7 and 26), and membrane-type MMPs (MMP-14, 15, 16, 17, 24 , and 25), among other types. They are found in all tissues and in plasma, being secreted mostly as pro-MMPs activated by the urokinase-plasminogen/plasmin system of cell membranes. In parallel and with regulatory and antagonistic action, four tissue inhibitors of MMPs (TIMPs) were described: TIMP-1, 2, 3, and 4. Hyperexpression of TIMP-1, 2 and 3 normally accompanies the course of tumor growth [2].

Studies performed so far on MMPs/TIMPs to assess risk for PCa seem to yield inconclusive results, with data on specificity and sensitivity being scarce. In this context, this minireview aimed at identifying studies that correlated circulating MMPs and TIMPs with $\mathrm{PCa}$, focusing on reports that aimed at having them tested as serum/plasma 


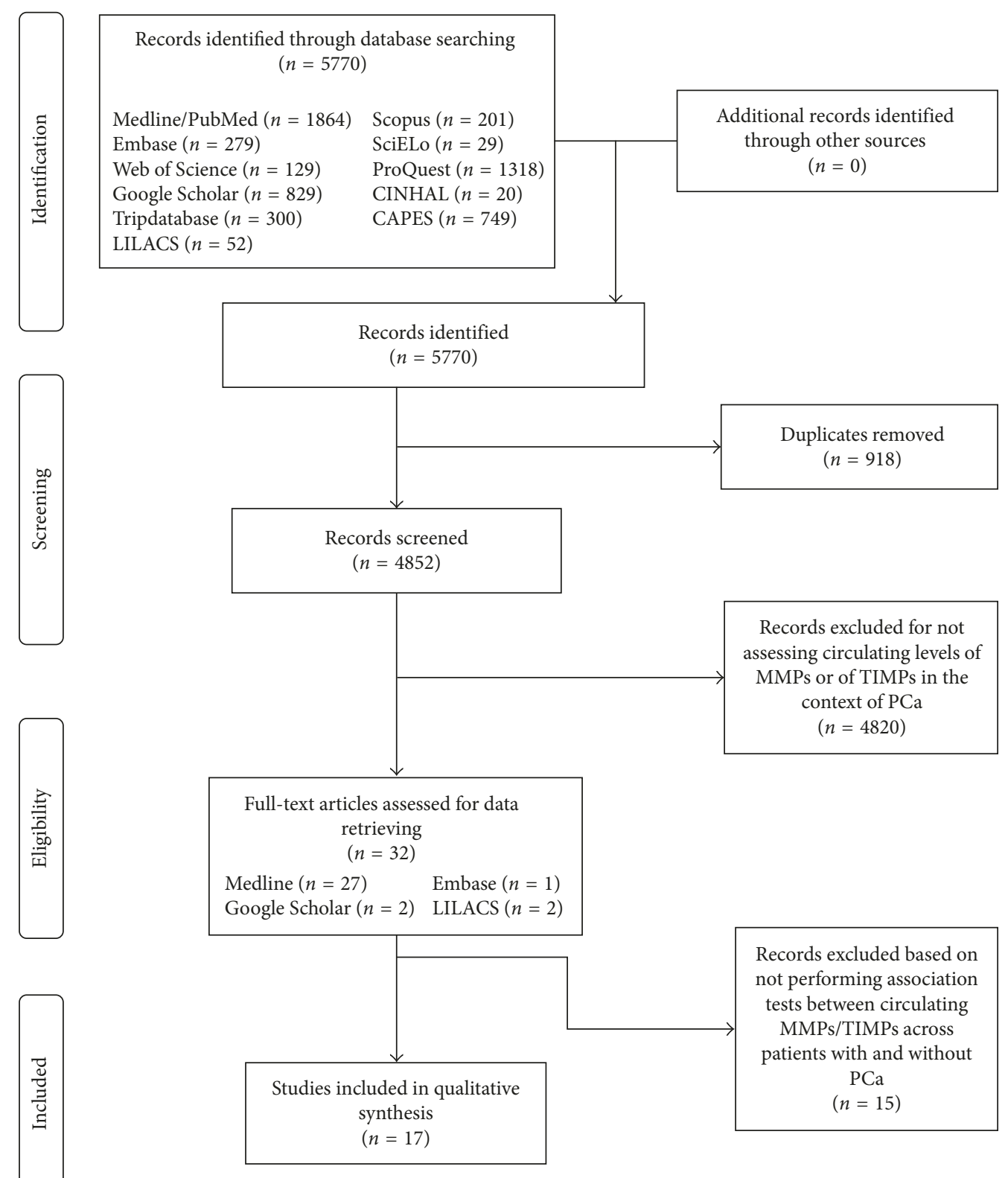

FIgURE 1: Rationale of the selection of articles.

biomarkers and describing accuracy scores, when available. A bibliographic survey was carried out in February and March 2017, using the following key words: metalloproteinases OR inhibitors of metalloproteinases OR MMPs OR TIMPs AND prostate cancer. The following quantitative studies were identified in the following primary databases: CINAHL, 20; EMBASE, 141; Google Scholar, 500; Library COCHRANE, 0; LILACS, 52; MEDLINE, 1859; SCOPUS, 201; and Web of Science, 129, and also in the following secondary sources of information: CAPES theses and dissertations database, 749; SCIELO, 29; PROQUEST, 1318; and Tripdatabase, 295. This search, after excluding replicates, produced a total of 17 reports addressing association of plasma/serum MMPs and/or TIMPs with $\mathrm{PCa}$ (Figure 1), which were obtained, analyzed, and systematized as depicted in Table 1.
There is a higher prevalence of studies on MMP-2 and MMP-9. In 1998, Gohji et al. [20] accumulated evidence of the correlation between the higher serum levels of MMP-2 and tumor extension. The authors measured MMP-2 by ELISA in the serum of $98 \mathrm{PCa}$ patients, with $76 \mathrm{BPH}$ carriers and 70 healthy men. Serum levels of MMP-2 were significantly higher in the PCa group than in the healthy and $\mathrm{BPH}$ counterparts and even higher in patients with metastatic PCa. In line, Kanoh et al. [19] measured by ELISA serum MMP-2 and PSA levels of $51 \mathrm{PCa}$ patients and of $39 \mathrm{BPH}$ carriers. The result consisted of increasing serum levels of both along with disease progression. Very high values of MMP-2 (>950 ng/ml) and PSA (>300 ng/ml) were observed when bone metastases was observed. Those authors advocate that MMP-2 can be coupled to PSA for prognostic purposes in $\mathrm{PCa}$. 
TABLE 1: Summary of the 17 articles revised.

\begin{tabular}{|c|c|c|c|c|c|}
\hline Authors and title & Objective of the study & Design & Material and sample & $\begin{array}{c}\text { Analysis } \\
\text { method }\end{array}$ & Conclusion \\
\hline Baker et al. [4] & $\begin{array}{l}\text { To measure serum levels of } \\
\text { collagenases, stromelysins, } \\
\text { and TIMP-1 and } 2 \text { in } \\
\text { patients with PCa, before } \\
\text { treatment and } 6 \text { and } 12 \\
\text { months after starting. }\end{array}$ & $\begin{array}{c}\text { Prospective } \\
\text { cohort }\end{array}$ & $\begin{array}{l}\text { Test: serum of } 19 \\
\text { individuals with metastatic } \\
\text { PCa and } 16 \text { with PCa } \\
\text { without metastases. } \\
\text { Control: } 21 \text { patients with } \\
\text { rheumatoid arthritis and } \\
57 \text { healthy subjects without } \\
\text { rheumatoid arthritis. }\end{array}$ & ELISA & $\begin{array}{l}\text { Increase of collagenases and } \\
\text { TIMP-1 in patients with } \\
\text { metastatic PCa compared to } \\
\text { those without metastases } \\
\text { and in the former in } \\
\text { relation to the control group } \\
\text { with or without rheumatoid } \\
\text { arthritis. } \\
\text { Reduction of TIMP-1 and } \\
\text { collagenase levels } 6 \\
\text { months after treatment. } \\
\text { After } 12 \text { months, the levels } \\
\text { of collagenases remained } \\
\text { low; however, those of } \\
\text { TIMP-1 returned to } \\
\text { pretreatment values. }\end{array}$ \\
\hline
\end{tabular}

To dose e-cadherin and MMP-13 at the diagnosis Bonaldi et al. [5] of PCa and three and six months after treatment, comparing with the control group.

$\begin{array}{cc}\text { Prospective } & \text { Test: plasma (EDTA) of } 29 \\ \text { cohort } & \text { PCa patients. } \\ & \text { Control: } 10 \text { healthy men } \\ \text { with PSA }<1.5 \mathrm{ng} / \mathrm{ml} .\end{array}$

No difference between mean MMP-13 values among test and control groups at any test period.

ELISA

Differences of MMP-9 and TIMP-1 (but not MMP-2) between groups; significant increase of

Test: plasma (heparin) of 96 patients with PCa.

To compare levels of Castellano et al. [6] osteopontin (OPN), MMP- Cross-sectional 2, MMP-9, and TIMP-1.
Control: 92 individuals with $\mathrm{BPH}$ and 125 healthy subjects.

ELISA

MMP-9 and reduction of TIMP-1 in the $\mathrm{CaP}$ group relative to the healthy and BPH control; decreased serum levels of MMP-9 six months after radical prostatectomy.

\section{Correlate preoperative} serum levels of 6 markers (including MMPs-2 and 9

Cicco et al. [7] and TIMPs-1 and 2) with

To compare TIMP-1 levels of castrated metastatic PCa

Gong et al. [8] patients with noncastrated Incorvaia et al. [9] individuals with PCa with bone metastases in relation
To compare levels of MMP-1, MMP-3, and TIMP-1 as well as the

Jung et al. [10]

\author{
Serum of 162 PCa carriers \\ Cross-sectional for MMP-2 and 9 and \\ plasma (EDTA) for TIMP- \\ 1 and 2.
}

Patients with serum levels of MMP- $2<206 \mathrm{ng} / \mathrm{ml}$ had a higher risk of $\mathrm{PCa}$ progression. tumor staging, Gleason score, and disease-free survival. (responsive to androgen ablation therapy).

To compare levels of MMP-2 and 9 in to healthy individuals.

ELISA

Test: serum of 39 castrated metastatic PCa patients. Control: 24 noncastrated metastatic PCa patients.

Test: plasma (EDTA) of 35 patients with breast cancer and 44 with PCa with bone metastases.

Control: 57 healthy patients.

\section{Plasma (heparin) of 47} patients with prostate cancer, 29 with no metastasis (T2, 3pN0M0), MMP-1/TIMP-1 ratio of subjects with metastatic

$\mathrm{PCa}$ and with nonmetastatic PCa.
Cross-sectional and 18 with metastasis (T2,

$$
\text { 3, 4pN1, 2M1). }
$$

Control: 35 healthy subjects and 29 with $\mathrm{BPH}$.
Higher TIMP-1 serum

ELISA levels in castrated PCa patients.
MMP-2 and MMP-9 significantly higher in $\mathrm{PCa}$ patients with bone metastases than in the control group.

Mean MMP-1 and TIMP-1 scores were significantly higher in the metastatic $\mathrm{PCa}$ group than in the ELISA nonmetastatic PCa, BPH, and healthy subjects groups. 10 of the 18 patients with metastatic PCa presented high levels of TIMP-1. 
TABle 1: Continued.

\begin{tabular}{|c|c|c|c|c|c|}
\hline Authors and title & Objective of the study & Design & Material and sample & $\begin{array}{c}\text { Analysis } \\
\text { method }\end{array}$ & Conclusion \\
\hline Morgia et al. [11] & $\begin{array}{l}\text { To measure plasma levels } \\
\text { of MMPs-2, } 9 \text {, and } 13 \text { of } \\
\text { TIMP-1, and of the } \\
\text { enzymatic activity of } \\
\text { MMPs- } 2 \text { and } 9 \text { in patients } \\
\text { with metastatic PCa, } \\
\text { nonmetastatic PCa, BPH, } \\
\text { and healthy, at diagnosis } \\
\text { and } 90 \text { days after starting } \\
\text { treatment. }\end{array}$ & Cohort & $\begin{array}{c}\text { Plasma (heparin) of } 40 \\
\text { patients with prostate } \\
\text { cancer, } 20 \text { with no } \\
\text { metastasis and } 20 \text { with } \\
\text { metastasis. } \\
\text { Control: } 20 \text { healthy } \\
\text { patients and } 20 \text { with } \\
\text { BPH. }\end{array}$ & ELISA & $\begin{array}{l}\text { Plasma levels of MMP-2, } \\
9 \text {, and } 13 \text { higher at } \\
\text { diagnosis in the PCa } \\
\text { group with metastasis } \\
\text { than in the other groups, } \\
\text { with reduction after } \\
\text { treatment. } \\
\text { Decreased TIMP-1 in the } \\
\text { PCa group with metastasis } \\
\text { in relation to the healthy } \\
\text { group but without } \\
\text { significant difference } \\
\text { between groups. }\end{array}$ \\
\hline
\end{tabular}

Test: plasma (EDTA) of 362 castrated PCa patients; sample was divided into two groups: one with 60 (pilot group) individuals with a follow-up time of 5.8 years and the other with 302 (primary group) participants followed by 6.6 years.
To evaluate TIMP-1 as

Oh et al. [12] castrated PCa patients.
Survival study rar
Lower survival rates

ELISA among individuals with higher levels of TIMP-1 in both groups.
To determine sensitivity, specificity, and predictive values for MMP-2 as a biomarker for PCa.

\section{Diagnostic} study
Test: serum of $34 \mathrm{PCa}$ patients.

Control: 79 patients without $\mathrm{PCa}$.
Prior et al. [13] To dose MMP-9 in patients
who underwent prostate Cross-sectional
biopsy.
Test: serum of 32 patients with positive biopsy (PCa group)

Control: 58 patients with negative biopsy.

Test: serum of 35 individuals with $\mathrm{PCa}$ with bone metastasis.

To evaluate the prognostic value of MMP-2 and

Salminen et al. [15] MMP-9 in PCa with and without bone metastasis, comparing with ALP and PSA.
Cross-sectional and prognostic
Control: 49 individuals

with PCa without bone metastasis.
Increased levels of MMP2 among subjects with PCa compared to the group without $\mathrm{PCa}$. Sensitivity: $24.1 \%$; specificity: 78.6\%; PPV: 31.8\%; NPV: $71.4 \%$. Cutoff of $718.36 \mathrm{ng} / \mathrm{ml}$

(mean level of MMP-2 in those without $\mathrm{PCa}$ ).

ELISA No difference in MMP-9 levels between groups.

No differences in MMP-2 and 9 levels between groups.

ELISA MMP-2 and 9 presented low accuracy for the diagnosis of bone metastasis in $\mathrm{PCa}$ and were not associated with survival.

Higher serum levels of MMP-7 in PCa patients

To compare serum levels of Test: serum of 93 individuals with localized

Szarvas et al. [16] with and without metastasis and to assess its prognostic value.
Cross-sectional PCa and 13 PCa cases with and prognostic bone metastasis. Control: 19 healthy individuals.
ELISA with distant metastasis; specificity of $69 \%$ and sensitivity of $92 \%$ for detection of metastasis.
To search mRNA and enzymatic activity of MMP-2 and 9 in prostatic tissue and serum of $\mathrm{PCa}$

Zhang et al. [17] patients (with and without metastasis) comparing with $\mathrm{BPH}$ and healthy
Test: serum of $15 \mathrm{PCa}$ patients with metastasis Cross-sectional and 10 without metastasis.

Control: $26 \mathrm{BPH}$ patients and 20 healthy.
RT-PCR and enzymatic activity of zymography MMP-9 compared to the other groups. 
TABLE 1: Continued.

\begin{tabular}{|c|c|c|c|c|c|}
\hline Authors and title & Objective of the study & Design & Material and sample & $\begin{array}{l}\text { Analysis } \\
\text { method }\end{array}$ & Conclusion \\
\hline $\begin{array}{l}\text { Gil-Ugarteburu } \\
\text { et al. [18] }\end{array}$ & $\begin{array}{l}\text { To correlate the } 1562 \mathrm{C} / \mathrm{T} \\
\text { polymorphism of the } \\
\text { MMP-9 gene with its } \\
\text { plasma levels. }\end{array}$ & $\begin{array}{c}\text { Prospective } \\
\text { cohort }\end{array}$ & $\begin{array}{l}\text { Test: plasma (heparin) of } \\
90 \text { patients submitted to } \\
\text { prostatic biopsy with } \\
\text { positive results for PCa. } \\
\text { Control: } 135 \text { with negative } \\
\text { biopsy for PCa. }\end{array}$ & ELISA & $\begin{array}{c}\text { No correlation between } \\
\text { the gene polymorphism } \\
\text { and plasma concentration } \\
\text { of MMP-9. }\end{array}$ \\
\hline Kanoh et al. [19] & $\begin{array}{c}\text { To correlate the serum } \\
\text { levels of MMP- } 2 \text { and PSA } \\
\text { with the different stages of } \\
\text { PCa. }\end{array}$ & Cross-sectional & $\begin{array}{l}\text { Test: serum of } 51 \mathrm{PCa} \\
\text { patients. } \\
\text { Control: serum of } \\
39 \mathrm{BPH} .\end{array}$ & ELISA & $\begin{array}{l}\text { MMP-2 and PSA levels } \\
\text { associated with metastatic } \\
\text { PCa; higher levels of } \\
\text { MMP-2 }(>950 \mathrm{ng} / \mathrm{ml}) \text { and } \\
\text { PSA }(>300 \mathrm{ng} / \mathrm{ml}) \text { in PCa } \\
\text { with bone metastasis. }\end{array}$ \\
\hline Gohji et al. [20] & $\begin{array}{l}\text { To compare MMP-2 levels } \\
\text { between individuals with } \\
\text { and without PCa. }\end{array}$ & Cross-sectional & $\begin{array}{c}\text { Test: serum of } 98 \\
\text { individuals with PCa } \\
\text { without previous } \\
\text { treatment. } \\
\text { Control: serum of } 76 \\
\text { individuals with BPH and } \\
70 \text { healthy. }\end{array}$ & ELISA & $\begin{array}{l}\text { Higher levels of MMP- } 2 \text { in } \\
\text { the PCa than in the } \\
\text { control group. }\end{array}$ \\
\hline
\end{tabular}

$\mathrm{BPH}=$ benign prostate hyperplasia; $\mathrm{MMP}=$ matrix metalloproteinase; $\mathrm{NPV}=$ negative predictive value; $\mathrm{PCa}=$ prostate cancer; $\mathrm{PPV}=$ positive predictive value; TIMP $=$ tissue inhibitor of metalloproteinase.

In this same sense, the study by Morgia et al. [11] investigated the use of MMPs as circulating biomarkers for the diagnosis and prognosis of PCa. Levels of MMP-2, 9, and 13 were significantly higher among PCa patients than in healthy or HPB subjects. The authors concluded that serum MMPs can be used as adjuvant biomarkers (combined with PSA) for the diagnosis (MMP-13) and prognosis (MMP-2 and MMP-9) of PCa. In addition, Prior et al. [13] also measured MMP-2 (and others, including PSA) in serum (and urine) of 113 men, stating that MMP-2 assessed in combination with PSA increases sensitivity for the diagnosis of PCa.

Likewise, Zhang et al. [17] investigated enzyme activity by zymography of MMPs-2, among others, in the serum of healthy men $(n=20)$, with $\mathrm{BPH}(n=26)$, with localized PCa $(n=10)$, and with metastatic PCa $(n=15)$. The results indicated significant differences in enzyme activity between groups for MMP-9 but not for MMP-2. Thus, unlike previous studies, it was concluded that only serum levels of MMP-9 would be correlated with the presence of malignancy and metastases.

Incorvaia et al. [9] measured serum MMP-2 and 9 in patients with breast and prostate cancer, with and without bone metastases. Regarding PCa, both MMPs were significantly higher in patients with PCa compared to control subjects, but being indistinguishable between subjects with and without bone metastases, conversely to Kanoh et al. Therefore, it was concluded that MMPs (mainly MMP-2) display low accuracy for the diagnosis of bone metastatic PCa. Salminem et al. [15] obtained the same conclusions as Incorvaia et al. [9] on the accuracy of MMP-2 and 9 in the diagnosis of bone metastatic PCa, compared to the accuracy of PSA and alkaline phosphatase, contraindicating the testing of these MMPs for diagnostic purpose. Likewise, MMP-9 was the target of Gil-Ugarteburu et al. [18], which correlated MMP-9 plasma concentrations of 235 patients (measured by ELISA) with the $1562 \mathrm{C} / \mathrm{T}$ polymorphism of the promoter region of the gene. Among the findings, the authors did not identify differences in the circulating concentrations of MMP-9 in the derived subgroups or any correlation with the polymorphism investigated.

In contrast, Castellano et al. [6] evidenced that serum levels of MMP-9 and its activator, osteopontin, declined significantly 6 months after prostatectomy. They also identified a correlation between serum MMP-9 and PSA and Gleason staging values. De Cicco et al. [7] quantified MMP2, MMP-9, TIMP-1, and TIMP-2 among other molecules in the plasma of 162 men diagnosed with PCa, having found only a significant association between low MMP-2 values (less than $206 \mathrm{ng} / \mathrm{ml}$ ) and an worsened disease progression (corrected $\mathrm{HR}=1.7$ and $\mathrm{CI}=95 \%$ ).

González Rodrigues et al. [14] found unsatisfactory results when serum MMP-9 was determined by ELISA in 100 patients with indication for prostate biopsy (prospective cohort study). Of these, 32 were diagnosed with PCa with $52 \%$ classified with Gleason greater than or equal to 7 . No significant difference in MMP-9 levels was found between groups with $\mathrm{PCa}$ and benign or uncertain histological results. No association was found between MMP-9 levels and PSA or Gleason scores.

Concerning other varieties of MMPs, Jung et al. in 1997 [10] performed ELISA assessments for plasma MMP-1, 3, and TIMP-1 on 19 nonmetastatic PCa, 18 metastatic, and 29 HPB patients, along with 35 healthy men. No difference was found in the MMP-1 means across groups. The mean concentration of MMP-3 and TIMP-1 in metastatic patients was significantly higher than in the other groups, with 10 out of the 18 metastatic cases displaying remarkably high levels of TIMP-1. They concluded that TIMP-1 can be correlated with the PCa 
condition. Previously, Baker et al. [4] also found higher levels of TIMP-1 (but not TIMP-2) in patients with PCa.

Serum MMP-7 was investigated by Szarvas et al. [16] using ELISA in 93 patients with focal PCa at the preoperative stage, along with 13 patients with bone metastases and 19 normal individuals. No statistically significant difference was found between PCa carriers and normal individuals. However, MMP-7 levels were significantly elevated in patients with metastatic PCa compared to focal counterparts, with specificity and sensitivity of 69 and $92 \%$, respectively, when a cutoff point of $3.7 \mathrm{ng} / \mathrm{ml}$ was adopted.

Plasma TIMP-1 was also the subject of Oh et al. [12] in a cohort study with mean follow-up of 6.6 years. Based on 362 samples from hormone-resistant and castrated patients with metastatic PCa, patients with higher levels of plasma TIMP-1 had the lowest survival (19 versus 43 months). Values of PSA, alkaline phosphatase, and Gleason scores were also considered. Plasma TIMP-1 was shown as the best predictor of survival in patients with these characteristics and independently of other classic markers.

Bonaldi et al. [5] correlated serum levels of e-cadherin and MMP-13 on PCa patients with serum levels of total PSA, free PSA, total testosterone, and clinical evolution, measured before onset of treatment as well as three and six months afterwards. The same was done in a parallel control group. At baseline, e-cadherin titers were lower in the PCa group than in the control group while for MMP-13, differences were not noticed. With treatment, authors identified only positive correlation between PSA and e-cadherin levels in the third month of treatment. Gong et al. [8] compared circulating TIMP-1 in hormone-resistant PCa patients who underwent orchiectomy with patients responsive to hormone therapy. In the first group, plasma TIMP-1 was significantly higher.

Thus, with regard to MMPs as circulating biomarkers to diagnose and monitor PCa, we conclude that very few studies were conducted in this matter, having rendered contradictory and inconclusive data. Nonetheless, the premise of differential levels in circulating MMPs among PCa patients for a diagnostic purpose seems worth investigating in light of evidence already existent for other neoplastic entities [21], with emphasis on what concerns MMP-2, 7, and 9 and TIMP-1 in the opinion of the authors of this minireview.

Although having reviewed seventeen scientific papers, it was not possible to meta-analyze results due to methodological heterogeneities and poor description of central tendency scores. Only five articles reported mean values for the plasma/serum markers assessed, three of which for MMP-2 and MMP-9 while the others for MMP-7 and TIMP-1 each. Specificity and sensitivity were only described in 1 study [13].

Considering that the current screening diagnosis, based on serum PSA dosage and rectal examination, has a limited accuracy (mainly specificity) for differentiation of PCa from other prostatic diseases and considering the fragility of the results pointed out in this review, more studies with the aim of confirming (or excluding) MMPs and TIMPs as elective biomarkers for PCa should be welcomed, either for diagnosis, prognosis, or therapeutic referral.

\section{Conflicts of Interest}

No potential conflicts of interest exist.

\section{Authors' Contributions}

William Khalil El-Chaer executed the bibliographical research and systematized the data obtained. William Khalil El-Chaer and Otávio Toledo Nóbrega analyzed and interpreted results as well as prepared the original manuscript. Clayton Franco Moraes critically revised the manuscript.

\section{Acknowledgments}

The research was supported with grants from CNPq (no. 445692/2014) and FAPDF (193.001.240/2016), with a fellowship for productivity in research to O.T. Nóbrega (CNPq).

\section{References}

[1] Epidemiology: epidemic rates of cancer incidence in Latin America," Nature Reviews Clinical Oncology, vol. 10, no. 6, p. 304, 2013.

[2] R. Visse and H. Nagase, "Matrix metalloproteinases and tissue inhibitors of metalloproteinases: structure function, and biochemistry," Circulation Research, vol. 92, no. 8, pp. 827839, 2003.

[3] E. I. Deryugina and J. P. Quigley, "Matrix metalloproteinases and tumor metastasis," Cancer and Metastasis Reviews, vol. 25, no. 1, pp. 9-34, 2006.

[4] A. H. Baker, D. R. Edwards, and G. Murphy, "Metalloproteinase inhibitors: biological actions and therapeutic opportunities," Journal of Cell Science, vol. 115, no. 19, pp. 3719-3727, 2002.

[5] C. M. Bonaldi, L. A. Azzalis, V. B. Junqueira et al., "Plasma levels of E-cadherin and MMP-13 in prostate cancer patients: correlation with PSA, testosterone and pathological parameters," Tumori Journal, vol. 101, no. 2, pp. 185-188, 2015.

[6] G. Castellano, G. Malaponte, M. C. Mazzarino et al., "Activation of osteopontin/matrix metalloproteinaes-9 pathway correlates with prostate cancer progression," Clinical Cancer Research, vol. 14, no. 22, pp. 7470-7480, 2008.

[7] C. De Cicco, L. Ravasi, L. Zorzino et al., "Circulating levels of VCAM and MMP-2 may help identify patients with more aggressive prostate cancer," Current Cancer Drug Targets, vol. 8, no. 3, pp. 199-206, 2008.

[8] Y. Gong, U. D. Chippada-Venkata, M. D. Galsky, J. Huang, and W. K. Oh, "Elevated circulating tissue inhibitor of metalloproteinase 1 (TIMP-1) levels are associated with neuroendocrine differentiation in castration resistant prostate cancer," The Prostate, vol. 75, no. 6, pp. 616-627, 2015.

[9] L. Incorvaia, G. Badalamenti, G. Rini et al., "MMP-2, MMP-9 and activin A blood levels in patients with breast cancer or prostate cancer metastatic to the bone," Anticancer Research, vol. 27, pp. 1519-1525, 2007.

[10] K. Jung, L. Nowak, M. Lein, F. Priem, D. Schnorr, and S. A. Loening, "Matrix metalloproteinases 1 and 3, tissue inhibitor of metalloproteinase-1 and the complex of metalloproteinase-1/ tissue inhibitor in plasma of patients with prostate cancer," International Journal of Cancer, vol. 74, no. 2, pp. 220-223, 1997.

[11] G. Morgia, M. Falsaperla, G. Malaponte et al., "Matrix metalloproteinases as diagnostic (MMP-13) and prognostic 
(MMP-2, MMP-9) markers of prostate cancer," Urological Research, vol. 33, no. 1, pp. 44-50, 2005.

[12] W. K. Oh, R. Vargas, S. Jacobus et al., "Elevated plasma tissue inhibitor of metalloproteinase-1 levels predict decreased survival in castration-resistant prostate cancer patients," Cancer, vol. 117, no. 3, pp. 517-525, 2011.

[13] C. Prior, F. Guillen-Grima, J. E. Robles et al., "Use of a combination of biomarkers in serum and urine to improve detection of prostate cancer," World Journal of Urology, vol. 28, no. 6, pp. 681-686, 2010.

[14] I. González Rodríguez, M. Rivas del Fresno, R. Gil Ugarteburu et al., "Expresión de metaloproteasa de matriz 9 en el cáncer de próstata: experiencia preliminar," Archivos Españoles de Urología, vol. 63, no. 2, pp. 119-124, 2010.

[15] E. K. Salminen, M. J. Kallioinen, M. A. Ala-Houala et al., "Survival markers related to bone metastases in prostate cancer," Anticancer Research, vol. 26, pp. 4879-4884, 2006.

[16] T. Szarvas, M. Becker, F. VomDorp et al., "Elevated serum matrix metalloproteinase 7 levels predict poor prognosis after radical prostatectomy," International Journal of Cancer, vol. 128, no. 6, pp. 1486-1492, 2011.

[17] L. Zhang, J. Shi, J. Feng, H. Klocker, C. Lee, and J. Zhang, "Type IV collagenase (matrix metalloproteinase-2 and -9) in prostate cancer," Prostate Cancer and Prostatic Diseases, vol. 7, no. 4, pp. 327-332, 2004.

[18] I. G. R. Gil-Ugarteburu, M. Rivas del Fresno, P. Benito García, A. Fenández Somoano, and A. Tardón García, "Plasmatic variations of metalloproteinase 9 (MMP-9) due to functional polymorphism in prostate cancer," Urology, vol. 80, no. 3, p. S276, 2012.

[19] Y. Kanoh, T. Akahoshi, T. Ohara et al., "Expression of matrix metalloproteinase-2 and prostate-specific antigen in localized and metastatic prostate cancer," Anticancer Research, vol. 22, no. 3, p. 1813, 2002.

[20] K. Gohji, N. Fujimoto, I. Hara et al., "Serum matrix metalloproteinase-2 and its density in men with prostate cancer as a new predictor of disease extension," International Journal of Cancer, vol. 79, no. 1, pp. 96-101, 1998.

[21] F. L. Fonseca, B. C. A. Alves, L. A. Azzalis, and T. M. Belardo, "Matrix metalloproteases as biomarkers of disease," Methods in Molecular Biology, vol. 1579, pp. 299-311, 2017. 


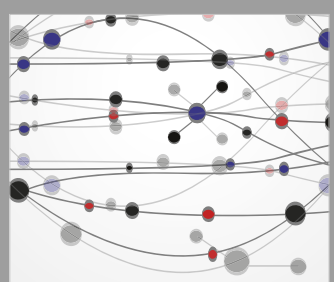

The Scientific World Journal




Gastroenterology Research and Practice

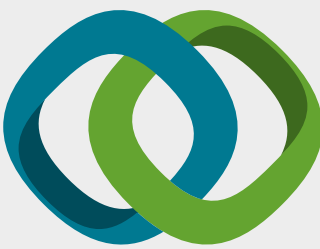

\section{Hindawi}

Submit your manuscripts at

www.hindawi.com
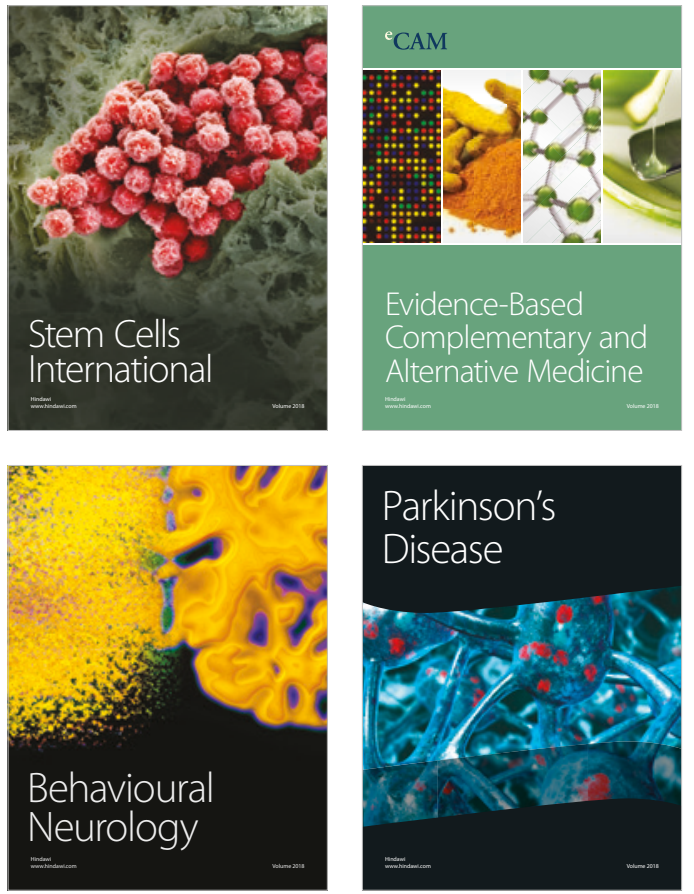



ournal of

Diabetes Research

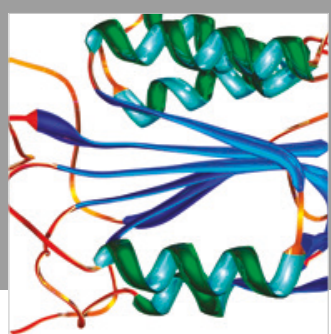

Disease Markers
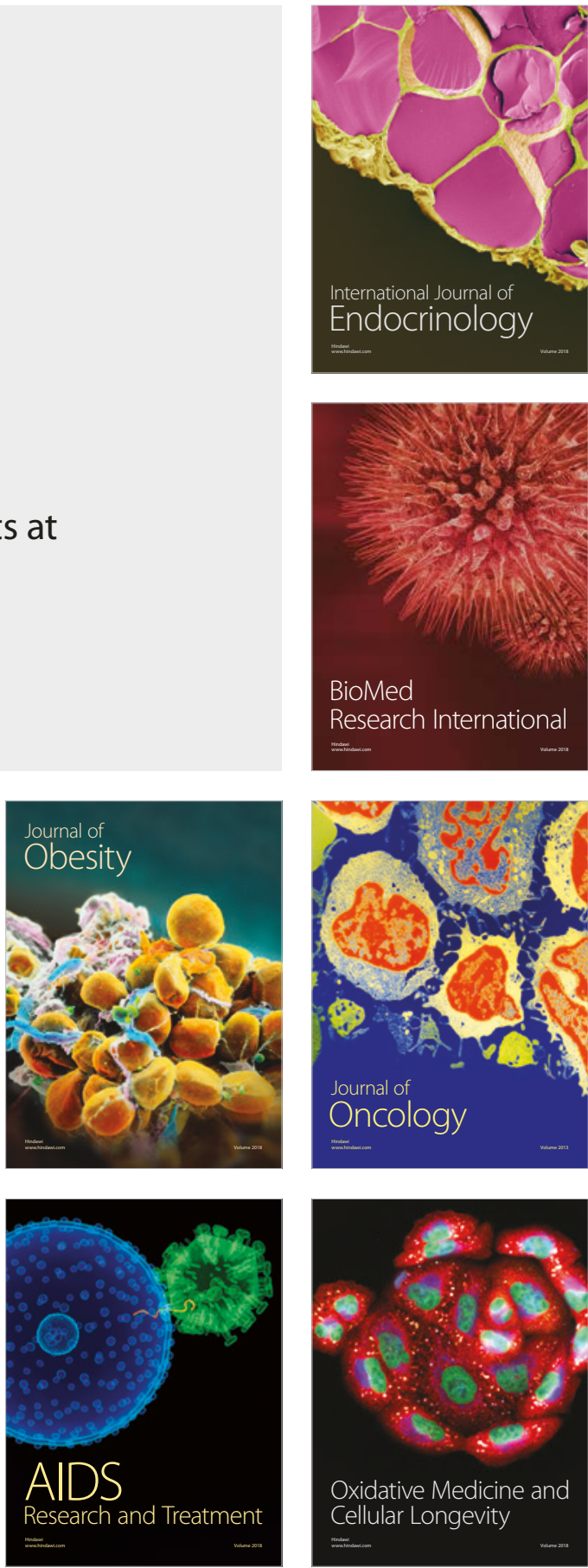